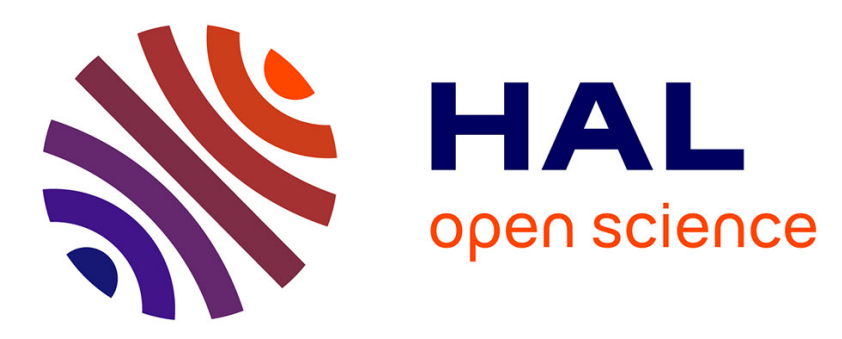

\title{
The relationship between farmers' attitude and behaviour towards calves, and productivity of veal units
} Joop Lensink, Alain Boissy, Isabelle Veissier

\section{To cite this version:}

Joop Lensink, Alain Boissy, Isabelle Veissier. The relationship between farmers' attitude and behaviour towards calves, and productivity of veal units. Annales de zootechnie, 2000, 49 (4), pp.313-327. 10.1051/animres:2000122 . hal-00889898

\section{HAL Id: hal-00889898 https://hal.science/hal-00889898}

Submitted on 1 Jan 2000

HAL is a multi-disciplinary open access archive for the deposit and dissemination of scientific research documents, whether they are published or not. The documents may come from teaching and research institutions in France or abroad, or from public or private research centers.
L'archive ouverte pluridisciplinaire HAL, est destinée au dépôt et à la diffusion de documents scientifiques de niveau recherche, publiés ou non, émanant des établissements d'enseignement et de recherche français ou étrangers, des laboratoires publics ou privés. 


\title{
Original article
}

\section{The relationship between farmers' attitude and behaviour towards calves, and productivity of veal units}

\author{
Joop LensinK*, Alain BoISSY, Isabelle VeISSIER \\ INRA, Centre de Recherches de Clermont-Ferrand-Theix, \\ Unité de Recherches sur les Herbivores, 63122 Saint-Genès-Champanelle, France
}

(Received 21 December 1999; accepted 4 May 2000)

\begin{abstract}
Although veal production is highly standardised, there still remains variability in productivity between farms, which might be due to the farmers' behaviour towards their animals, which in turn depends on their attitude towards animals. Fifty farms affiliated with the same veal company were studied. The farmers' behaviour with the calves was observed during one morning meal. The farmers were then asked to fill in questionnaires designed to measure their attitude towards calves, and to obtain information about their background (e.g. age, gender, level of education). The productivity results (daily weight gain, feed conversion, and mortality rates) were obtained from the veal company. The frequency of gentle contacts was positively correlated with the description the farmers made of their behaviour with the calves and their beliefs about the sensitivity of calves. Female farmers showed a more positive behaviour towards the calves, had more positive beliefs about the importance of contacts with calves, and made a more positive description of their own behaviour. Positive behaviour was associated with better productivity. Furthermore, bigger units had lower mortality rates. It is concluded that for veal farmers, a positive attitude towards calves, a positive behaviour towards them, and good production results are linked.
\end{abstract}

veal calves / human-animal relationship / handling / behaviour / attitude

Résumé - Relation entre l'attitude et le comportement des éleveurs envers les animaux, et la production de veaux de boucherie. Bien que la production de veaux de boucherie soit très standardisée, il reste une certaine variabilité dans les résultats techniques entre élevages. Cette variabilité résiduelle pourrait être due à la façon dont les éleveurs se comportent envers leurs animaux. Cette étude a pour objectifs de décrire le comportement des éleveurs avec leur veaux, d'en comprendre l'origine (en fonction de l'histoire des éleveurs et de leurs attitudes envers les veaux), et d'évaluer la relation entre la productivité des élevages et le comportement et l'attitude des éleveurs. Cinquante élevages affiliés au même intégrateur ont été étudiés. Tous utilisaient la même alimentation

* Correspondence and reprints

Tel.: 33 (0)4 736240 98; fax: 33 (0)4 736241 18; e-mail: lensink @ clermont.inra.fr 
et recevaient le même suivi technique. Les contacts et les mouvements de l'éleveur ont été observés pendant la distribution du lait aux veaux. Puis les éleveurs ont été interviewés au moyen de deux questionnaires. Le premier visait à déterminer leurs attitudes envers les veaux : des questions sur leurs croyances concernant la sensibilité des veaux au comportement humain, sur l'importance des contacts humains pour la réussite de l'élevage, et sur la fréquence des contacts donnés par eux-mêmes, étaient posées. Le second visait à obtenir des informations sur l'histoire des éleveurs (par exemple âge, genre, niveau d'éducation). Des analyses en composantes principales ont été réalisées pour évaluer la cohérence à l'intérieur de chacun de ces groupes de données et pour calculer des variables synthétiques. Les données sur la croissance des veaux, l'indice de consommation et la mortalité ont été fournies par l'intégrateur après les observations. Les résultats montrent que les éleveurs qui ont un comportement positif envers les veaux (contacts doux fréquents et contacts brusques rares) ont également une attitude positive envers les animaux (ils croient en leur sensibilité) et attribuent plus d'importance aux contacts qu'ils donnent. Les éleveurs-femmes ont montré un comportement plus positif envers les veaux, et également une attitude plus positive envers ce comportement (elles jugent les contacts importants et rapportent donner fréquemment des contacts doux). Les meilleurs résultats techniques ont été observés chez les éleveurs qui avaient le comportement le plus positif. De plus, la mortalité était moindre dans les plus grandes unités. En conclusion, parmi les éleveurs de veaux de boucherie, une attitude positive envers les veaux, un comportement positif avec eux, et de bons résultats techniques sont liés. De plus, les femmes semblent avoir une attitude et un comportement plus positif envers les animaux.

veaux de boucherie / relation homme-animal / manipulation / comportement / attitude

\section{INTRODUCTION}

Most of the veal production in Europe takes place on integrated farms. Despite the fact that farms affiliated to the same veal organisation receive similar inputs in terms of calves, feed, feeding plans, and technical advice, there still remain variations in productivity results between farms. According to data provided by a French veal organisation, daily weight gain per calf can vary around $65 \mathrm{~g} \cdot \mathrm{d}^{-1}$ and feed conversion ratios can vary around 0.12 between farms supposed to have highly comparable inputs. Some technical aspects affecting climate in buildings may account for these variations. However, concerning the farms between which the variables were measured, all buildings are regularly checked and received approval by the veal industry, and it is therefore likely that variations in productivity are, at least in part, due to aspects of the farmers. Slight differences in the farmer's individual management strategy, such as frequency of routine checks of animals and facilities, and hygiene, but also their personality [30] and interactions with the animals might be the reason for these variations in productivity.

Studies in the pig and poultry industries, where the major inputs to the farms were similar, have demonstrated the importance of the stockperson's contact with animals on the behaviour, physiology and productive performance of these animals [2, 17, 18]. In pigs reared under experimental conditions, negative interactions, like hits, slaps or electrical shocks by a prodder, lead to an increased avoidance of humans [10, 14, 27], and elevated chronic corticosteroid levels $[15,16]$. This chronic stress is likely to reduce the feed efficiency and growth of the animals $[14,16]$, for instance by disrupting protein metabolism [25]. In addition to physical contact, visual appearance of people might be of importance for animals housed in restricted environments. In poultry, Barnett et al. [1] found that regular visual contact, including slow and deliberate movements, reduced the subsequent avoidance 
behaviour of laying hens, and led to improved egg production. These studies together with a recent study on dairy cows in which the fear of people was found to be associated with reduced milk yield and increased heart rate at milking [28], show the importance of the stockperson's behaviour towards the animals on behaviour and production. In the veal calf industry, a close relationship exists between the farmer and his calves, as on most of the farms generally only one person is responsible for the caretaking. Therefore, the behaviour of the farmer towards the calves may have a strong effect on the animal's behaviour and production.

Research in pig industry, trying to identify factors determining stockpersons' behaviour towards animals, revealed that stockpersons' behaviour is most closely related to the attitude they have towards animals $[3,17,19]$. Attitude is hereby defined as a "psychological tendency that is expressed by evaluating a particular entity with some degree of favour or disfavour' [4]. In these studies, stockpersons with a positive attitude towards pigs were found to show a lower percentage of negative contacts when working with them [17]. This body of research has been primarily based on Azjen and Fishbein's "theory of reasoned action" [7]. According to this theory, a person's intention to perform a behaviour results from his/her attitude towards that behaviour, combined with subjective norms. In turn, attitudes are linked with beliefs that the behaviour leads to a certain outcome and by the evaluation of these outcomes. The model furthermore proposes that other factors like personality and demographic variables (e.g. age, gender, education) modify indirectly someone's behaviour through their effect on attitudes. However, external factors could also affect someone's behaviour directly. A stockperson might intend to interact individually with all the animals, but work pressure, due to a high number of animals to take care of, might prevent him/her from interacting with them.
The present study aimed to describe the veal farmers' behaviour towards the calves within a sample of farms affiliated to the same veal organisation, and to relate this to the farmers' attitudes, their background and the productivity results of the veal unit. Despite European regulations, stating that calves should be reared in groups from the end of 2003 on (Directive No. 97/2/CE), only a few farms had group housed calves at the time of the study (end of 1997). It was therefore decided to conduct observations on farms where calves were housed in individual crates. As the work on veal units with individual crates is highly repetitive, standardised and similar for every farmer, we could conduct direct observations of their behaviour towards the calves.

\section{MATERIALS AND METHODS}

\subsection{Subjects}

Fifty veal farms were studied, which were all affiliated to the same veal producing organisation. All farms were situated in the same region (Bretagne, France), were family managed, and had between 100 and 700 calves which were housed in individual crates. Farms had similar inputs provided by the veal producing organisation, concerning feed, feeding schedule, management advice and calves (Holstein/ Friesian). Differences in productivity results could thus not be attributed to differences in general production strategies.

As the participants could have been sensitive to the objectives of the study, and this could have affected their behaviour and responses to questions asked, a dummy objective was given. The farmers were told that the observer wanted to observe the behaviour of the calves, and wanted to describe veal producers in general. Debriefing about the results of the study was performed after the study. 


\subsection{Measurements}

\subsubsection{Productivity results}

Productivity results in terms of daily weight gain, feed conversion and mortality rates (from 8 days of age on) were taken over the last three batches of calves. The results, expressed in deviation from the average of the farms affiliated with the veal organisation and finishing a batch of calves the same month, were provided by the veal organisation.

\subsubsection{Farmers' contacts with the calves}

The farmers' behaviour towards the calves was observed during one morning milk meal of the calves. During milk meals the farmer generally passes in front of the calves' crates, opens the front of the crates to allow the calves to access the bucket, meanwhile filling the individual buckets by means of a hose. At most of the farms only one person was present during milk meals. When more people were present only the person in charge of milk distribution was observed. During the observation, which lasted for at least 2 hours, the experimenter (the same person for all veal farms) followed the farmer at a distance of 5-10 metres and noted the number and nature of contacts between the farmer and the calves. Contacts observed were: touching briefly with hand the forehead of the calf ('touch forehead'), the snout ('touch snout'), or other parts of the head or neck ('touch other part'), petting any part of the body for at least 2 seconds ('petting'), extending the hand to let calf suck the fingers ('suck fingers'), giving a (floating) rubber teat (given to calves not drinking correctly from the bucket) (' $\mathrm{giv}$ ing teat'), making a slapping movement directed to the calves ('slapping movement'), slapping the calves with the hands or an object ('slapping contact'), kicking the calf ('kicking'), pushing the calf back in its crate ('pushing back'), letting the calf lick or nibble his/her clothing ('letting lick or nibble overall'), shouting in the barn ('shouting'), talking in a neutral way (not necessarily to the calves) ('talk neutral'), talking in a friendly tone to the calves ('talk friendly'), and any other contact that did not include the previous ones described ('other contact'). Contacts between farmers and calves were expressed in frequency per 100 calves.

\subsubsection{Farmers' movements}

Speed of walking and arm gestures of the farmer when distributing milk, when closing the feeding gates and when walking through the barn outside milk distribution, were noted on a scale from 1 to 5 . For speed of walking, 1 indicated 'very slowly and careful walking', 2 - 'slowly walking', 3 - 'walking at a moderate, steady pace', 4 - 'walking rapidly' and 5 - 'very fast walking, with occasional running'. For arm gestures, 1 indicated 'very slow and very careful gestures', 2 - 'slow and careful gestures', 3 - 'moderate gestures', 4 - 'rapid and some irregular gestures', and 5 - 'very rapid and irregular gestures'.

\subsubsection{Farmers' attitudes towards calves}

After the observations, the farmers were asked to fill in a questionnaire designed to infer their attitudes towards behaving with calves from:

(1) their beliefs about the sensitivity of veal calves to contacts from the farmer. Five statements were presented in the form of "Calves are sensitive to $x$ ", where $x$ was either 'contact in general', 'touching', 'talking', 'petting', or 'kicking';

(2) their beliefs about the importance of stockperson's behaviour for the success of the farm. Seven statements were given in the form of " $x$ calves is important for the success of the farm", where $x$ was either 'being patient with', 'working quietly with', 'having contact with', 'touching', 'talking to', 'petting', or 'letting suck your fingers'; 
(3) their description of their interactions with calves. Six questions in the form of "How often do you $x$ your calves" were asked, where $x$ was either 'touch', 'pet', 'talk to', 'let suck your fingers', 'slap with your hands', or 'kick'.

The answers on the statements in the first two categories were given on a $10 \mathrm{~cm}$ scale, whose left end corresponded to full disagreement with the statement and the right end to full agreement. The farmers were asked to put a cross between these two extremes. The value finally attributed to the answer was equivalent to the distance of the cross from the left end of the scale. Answers to the last category were given on a 7 point scale (with 1 = "never", 4 = "sometimes", and 7 = "very often").

\subsubsection{Farmers' background}

A second questionnaire was designed to obtain data on the background of the farmer. The following information was recorded: gender, age of the farmer, level of education, years of experience with veal production, agricultural background, parents having veal production, the size of the veal unit (number of calves), and other production types (like dairy or pig production) present on the farm. Level of education was further encoded on a scale from 1 to $3 ; 1$ indicated no specific education after (primary and) secondary school; 2 indicated attendance at an elementary course at an agricultural school (e.g. French diploma BEPA, CAP); 3 indicated advanced (including university level) education (e.g. French diploma BTS, BTA).

\subsection{Statistical analyses}

All statistics were performed by using the SAS statistical package [29].

Five principal component analyses were run to get synthetic variates describing farmers' contacts with the calves, farmers' movements, and the three attitude categories.
Principal component analysis permits data from a large number of variables to be organised into factors (called 'axes') based on the correlation they have with each other. The first axes can then be used to define synthetic variates, since they express most of the variability within the population observed. Axes will be presented only if their eigenvalue is higher than 1 [6]. To interpret these axes, variables with a loading greater than 0.3 will be commented. To analyse the consistency between farmers' behaviour and their attitudes, Pearson product correlations were calculated between those axes.

To examine relationships between background of the farmers, farmers' attitudes, farmers' behaviour, and production variables, stepwise multiple regressions were used. In this procedure, the best predictor enters the regression equation first. Additional variables are added based on the amount of remaining variance of the dependent variable they explain [9]. Alpha was 0.10 for entering the model, and 0.05 for staying in the model.

\section{RESULTS}

\subsection{Farmers' contacts with the calves}

The frequency of farmers' contacts with the calves was $30.3 \pm 3.7$ SE per 100 calves. The first axis of the Principal Component Analysis with an eigenvalue of 4.8, explained $32 \%$ of the variation of the original 15 variables. On this axis, petting, any form of touching the calves, talking friendly and letting suck the fingers, had high positive coefficients (Fig. 1). The higher the value on this axis, the more these acts were observed during milk distribution. This first axis will be labelled as "positive contacts". The second axis had an eigenvalue of 2.5 , and explained $16 \%$ of the variation. On this axis, slapping, shouting and talking neutral had high positive coefficients (Fig. 1). This axis will be labelled as "negative contacts". 

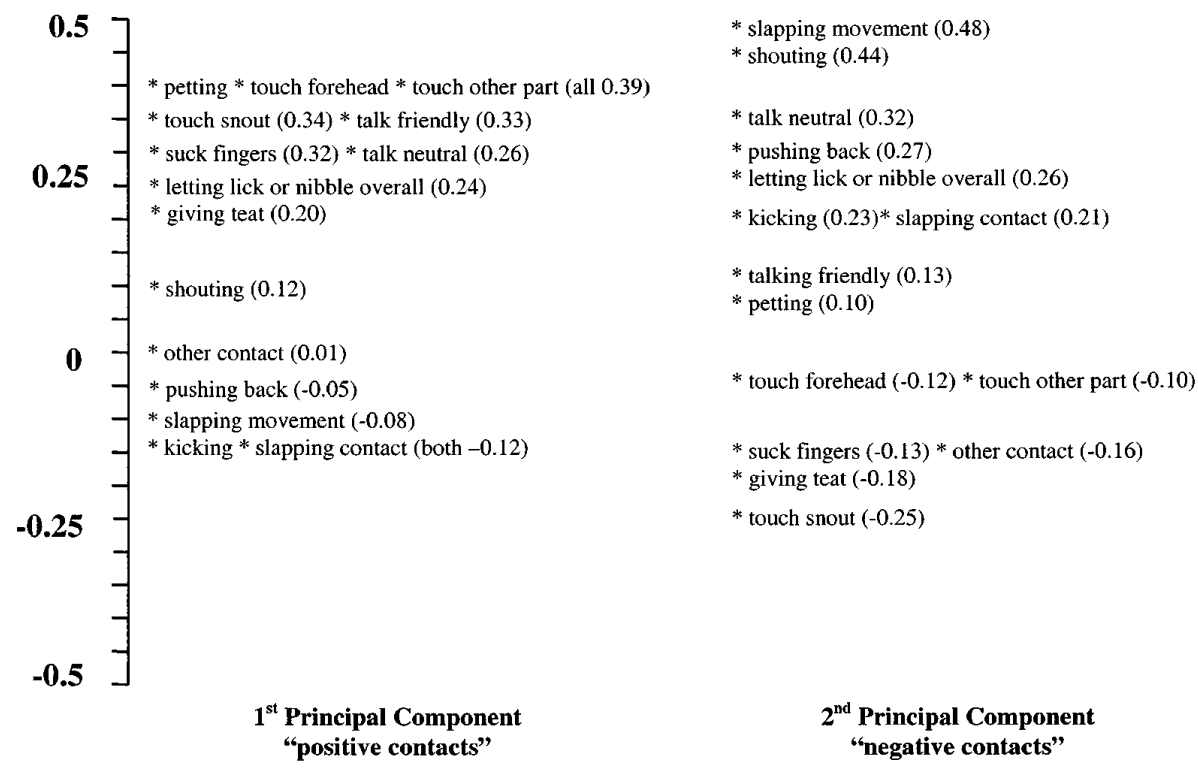

Figure 1. Principal Component Analysis of farmers' contacts with the calves. First two axes with contributions of the 15 variables of the observed farmers' contacts with the calves.

\subsection{Farmers' movements}

The first axis of the Principal Component Analysis run on the farmers' movements during working had an eigenvalue of 3.9 and explained $65 \%$ of the variation in the original 6 variables. All variables had contribution coefficients between 0.34 and 0.46 . The higher the value on this axis, the higher the speed of walking and the more irregular the gestures.

\subsection{Farmers' attitudes}

Principal Component Analysis on the statements on the sensitivity of the calves, revealed that two axes with eigenvalues of 2.1 and 1.1, respectively, explained $64 \%$ of the variation in the original five statements. The first axis had positive coefficients for all statements, and a high value on this axis indicates beliefs that calves are sensitive to farmers' contacts (Fig. 2). This axis will be labelled as "general sensitivity" (GENSENS). The second axis opposed statements on 'kicking' and 'talking' to 'contact in general' (Fig. 2). A high value on this axis indicates beliefs that calves are sensitive only to negative contacts and to human voice. This axis will be labelled as "specific sensitivity" (SPE-SENS).

Concerning the statements about the importance of contacts for the success of the veal unit, the first two axes of the Principal Component Analysis explained in total $67 \%$ of the variance, with eigenvalues of 3.2 and 1.5 , respectively. All statements had positive contributions on the first axis (Fig. 3). A high value on this axis indicated beliefs that any contact is important for the production. This axis will be labelled as "general importance" (GEN-IMP). The second axis opposed 'talking', 'petting' and 'letting suck fingers' to 'touching' and 'being patient' (Fig. 3). A high value on this axis indicates that importance is attributed 


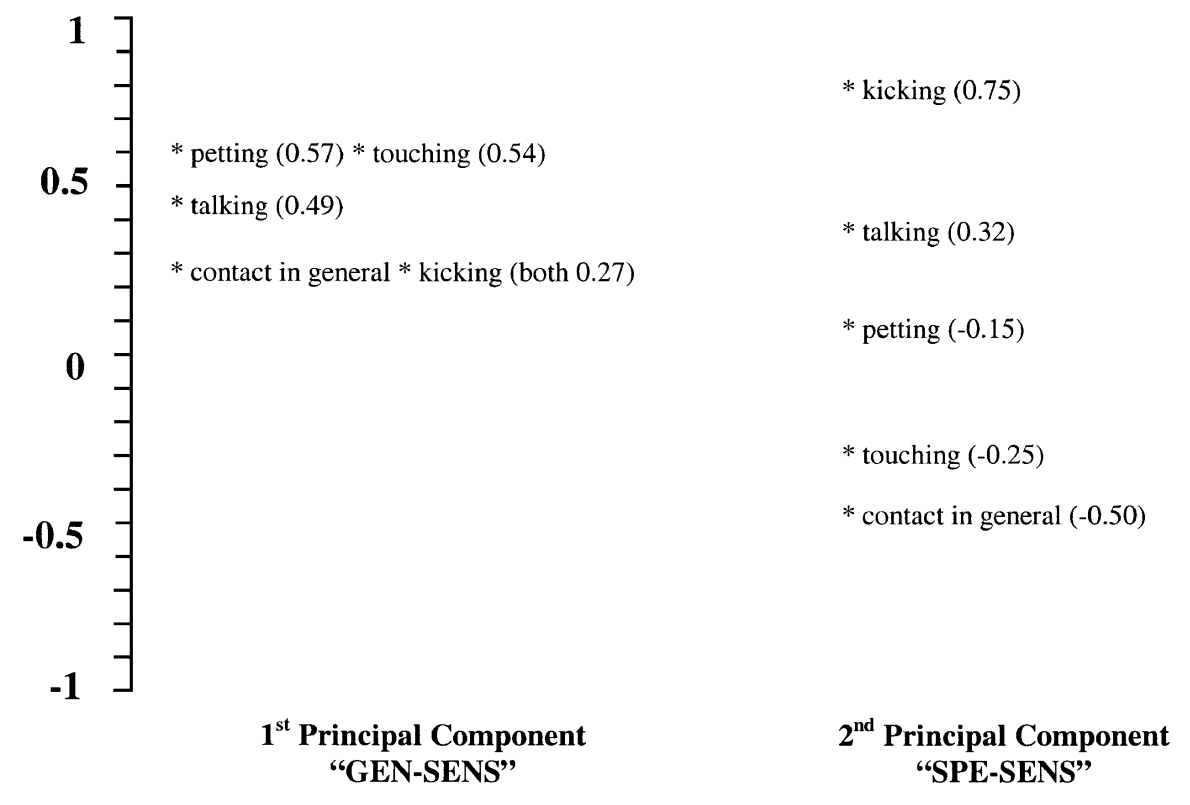

Figure 2. Principal Component Analysis of the attitude towards the sensitivity of the calves. First two axes with contributions of the 5 statements.

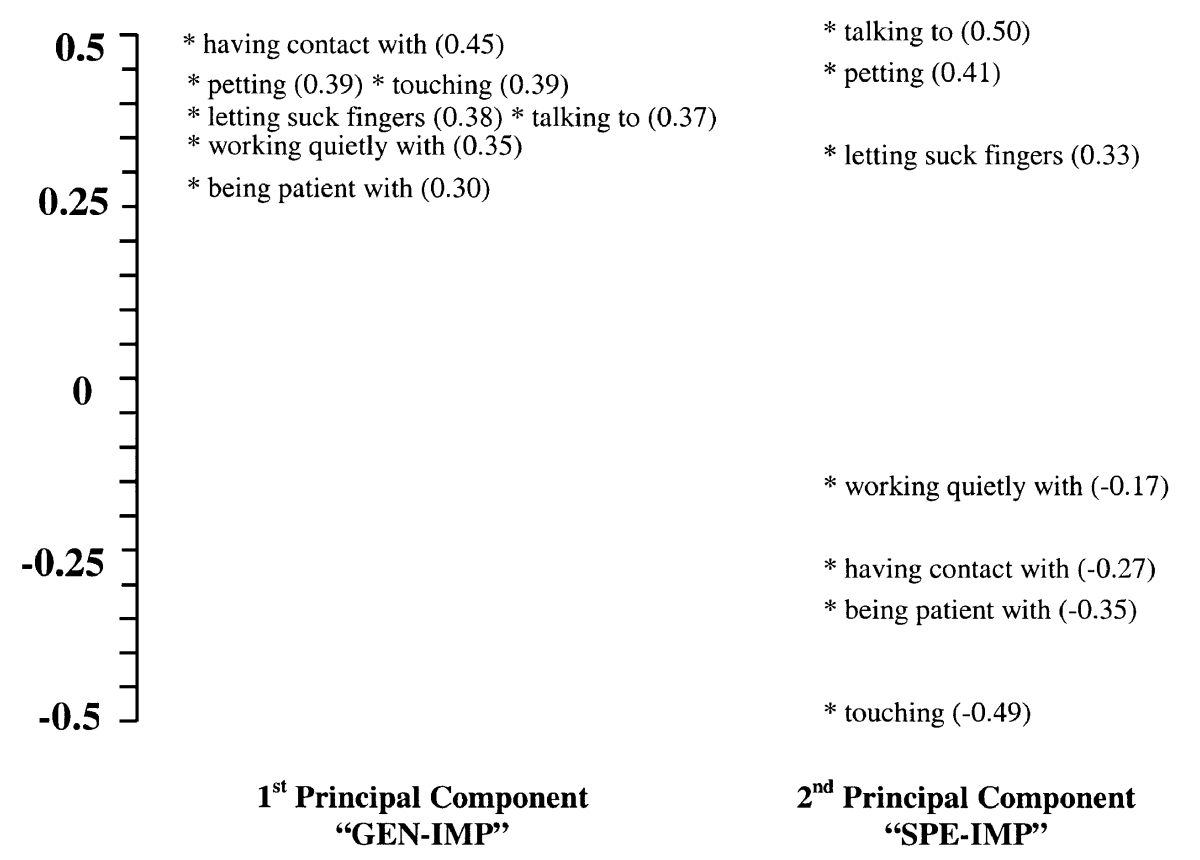

Figure 3. Principal Component Analysis of the attitude towards the importance of contacts with the calves for the success of the veal unit. First two axes with contributions of the 7 statements. 


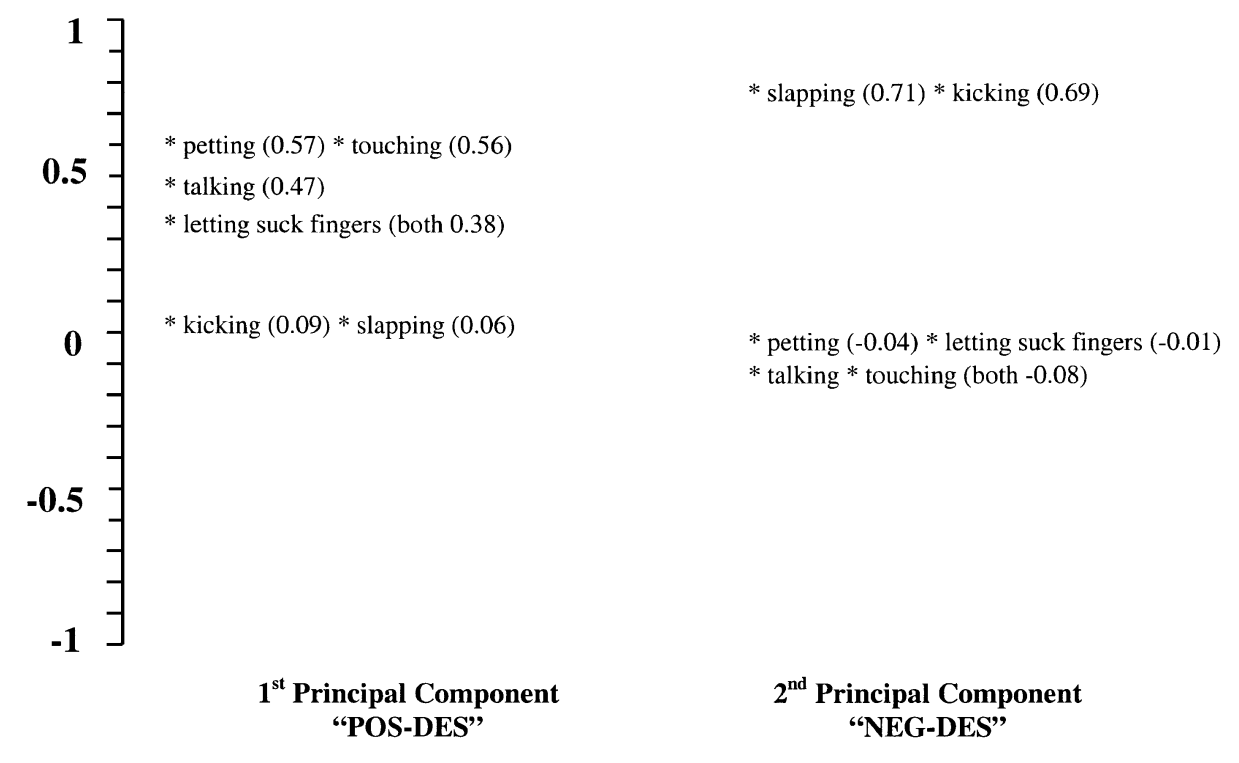

Figure 4. Principal Component Analysis on the farmer's description of his/her own contacts with the calves. First two axes with contributions of the 6 statements.

to specific (close) contacts with calves rather than general characteristics of farmers' behaviour. This axis will be labelled as "specific importance" (SPE-IMP).

The first two axes of the Principal Component Analysis on the description by the farmer of his/her interactions with the calves, explained $71 \%$ of the variance, with eigenvalues of 2.9 and 1.4 , respectively. The first axis had positive contribution coefficients for 'petting', 'touching', 'talking', and 'letting suck fingers' (Fig. 4). A high value on this axis indicates that the farmer reports giving often positive or neutral contacts to the calves, and this axis will therefore be labelled as "positive description" (POSDES). On the second axis, 'kicking' and 'slapping with your hands' had positive contribution coefficients. A high value on this axis indicates that the farmer reports giving often negative contacts to the calves, and this axis will therefore be labelled as " $n e g$ ative description" (NEG-DES).

\subsection{Farmers' background}

On 17 out of the 50 veal farms, a woman was in charge of the veal unit. The age of the farmers was $41 \pm 1.2$ (SE) years, the mean education level was $1.9 \pm 0.1$ (SE) and the number of years experience with veal production was $14.0 \pm 1.1(\mathrm{SE})$. All but 2 farmers had an agricultural background, and 16 had parents growing veal. The number of veal calves per farm was $269 \pm 16$ (SE). Twenty-two farmers had only veal production, twenty had a dairy unit next to veal calves, four farmers had either pigs or poultry, two had horses, and two had a non-animal production unit.

\subsection{Relations between farmers' behaviour, attitudes and background}

To analyse the consistency between farmers' behaviour and their attitudes, correlations between values obtained on the axes of the principal component analyses were 
Table I. Pearson product-moment correlations between farmers' contacts with the calves, movements around milk distribution, and attitude categories.

\begin{tabular}{|c|c|c|c|c|c|c|c|c|c|}
\hline & Positive contact & Negative contact & Movements & GEN-SENS & SPE-SENS & GEN-IMP & SPE-IMP & POS-DES & NEG-DES \\
\hline Positive contact & - & - & -0.27 & $0.43^{* *}$ & 0.22 & 0.26 & 0.27 & $0.55^{* *}$ & -0.11 \\
\hline Negative contact & & - & $0.46^{* *}$ & -0.10 & 0.01 & 0.18 & -0.06 & 0.08 & -0.19 \\
\hline Movements & & & - & -0.25 & -0.27 & -0.27 & -0.12 & -0.16 & 0.07 \\
\hline GEN-SENS $^{1}$ & & & & - & - & $0.33^{*}$ & $-0.34^{*}$ & $0.56^{* *}$ & 0.05 \\
\hline SPE-SENS ${ }^{2}$ & & & & & - & $0.29^{*}$ & 0.08 & 0.16 & 0.03 \\
\hline GEN-IMP ${ }^{3}$ & & & & & & - & - & $0.58^{* *}$ & $-0.32^{*}$ \\
\hline SPE-IMP ${ }^{4}$ & & & & & & & - & $0.38^{* *}$ & 0.23 \\
\hline POS-DES ${ }^{5}$ & & & & & & & & - & - \\
\hline NEG-DES ${ }^{6}$ & & & & & & & & & - \\
\hline
\end{tabular}

${ }^{*} P<0.05 ;{ }^{* *} P<0.01$.

${ }^{1}$ GEN-SENS: beliefs about the sensitivity of the calves to farmers' contacts in general.

${ }^{2}$ SPE-SENS: beliefs that calves are sensitive only to negative contacts and human voice.

3 SEN-IMP: bliefs that calves and human voce

4 GPE-IMP: beliefs that specife (close) contacts are improductivity of the veal unit.

${ }^{4}$ SPE-IMP: beliefs that specific (close) contacts are important.

6

(aven. 
Table II. Stepwise multiple regression analysis with farmers' behaviour as dependent variables and farmers' attitude and background data as independent variables.

\begin{tabular}{lcccccc}
\hline Dependent variable & Independent variable & $\beta$ & Partial R $^{2}$ & Model R $^{2}$ & $F$-value & $P$ \\
\hline Positive contact & POS-DES & 0.47 & 0.27 & & & \\
& Size veal unit & -0.25 & 0.06 & & & \\
& Gender & 0.23 & 0.04 & 0.37 & 7.83 & $<0.01$ \\
Negative contact & - & - & - & - & - & - \\
Movements & - & - & - & - & - & - \\
\hline
\end{tabular}

Table III. Stepwise multiple regression analysis with farmers' attitudes as dependent variables and background data as independent variables.

\begin{tabular}{lcccccc}
\hline Dependent variable & Independent variable & $\beta$ & Partial $^{2}$ & Model R $^{2}$ & $F$-value & $P$ \\
\hline GEN-SENS & - & - & - & - & - & - \\
SPE-SENS & - & - & - & - & - & - \\
GEN-IMP & Size veal unit & 0.38 & 0.09 & & & \\
& Gender & 0.36 & 0.08 & & & \\
& Education level & 0.27 & 0.07 & 0.24 & 4.88 & $<0.01$ \\
SPE-IMP & - & - & - & - & - & - \\
POS-DES & Gender & 0.31 & 0.10 & 0.10 & 5.04 & $<0.01$ \\
NEG-DES & - & - & - & - & - & - \\
\hline
\end{tabular}

calculated. Observed positive contacts with the calves were positively correlated to a positive attitude towards the sensitivity of the calves (GEN-SENS) and a positive description of the farmers' own behaviour (POS-DES) (respectively $r=0.43$ and $r=0.55, P<0.01$; Tab. I), while negative contacts were significantly correlated with speed of movements made $(r=0.46$, $P<0.01$; Tab. I), but not significantly correlated with any of the attitude categories. Farmers' movements around milk distribution were not significantly correlated with any of the attitude categories.

The first axes of the principal component analyses on attitudes (GEN-SENS, GENIMP, and POS-DES) were positively correlated with each other. Also a greater importance attributed to contacts (GENIMP) was associated with stronger beliefs about the sensitivity of the calves to kicking or talking (SPE-SENS) and less negative descriptions of their own behaviour (NEGDES), and a greater importance attributed to close contacts (SPE-IMP) was associated with a more positive description of own behaviour (POS-DES) (Tab. I)

In addition, regression analyses were performed to explain the behaviour of the farmers by attitude categories and background on the one hand, and to explain the attitude categories by background variables on the other hand. Attitude category 'POS-DES', gender, and size of the veal unit, were significant predictors of the amount of positive contacts given by the farmers to the calves $(P<0.01$; Tab. II), accounting together for $37 \%$ of the variance. A more positive description of own behaviour, smaller veal units, and female farmers, were associated 
Table IV. Stepwise multiple regression analysis with production variables as dependent variables and farmers' behaviour, attitude, and background data as independent variables.

\begin{tabular}{|c|c|c|c|c|c|c|}
\hline Dependent variable & Independent variable & $\beta$ & Partial $\mathrm{R}^{2}$ & Model $\mathrm{R}^{2}$ & $F$-value & $P$ \\
\hline \multirow[t]{2}{*}{ Daily weight gain $\left(\mathrm{g} \cdot \mathrm{d}^{-1}\right)$} & Positive contact & 0.29 & 0.15 & & & \\
\hline & Movements & -0.31 & 0.07 & 0.22 & 6.79 & $<0.01$ \\
\hline Feed conversion & Positive contact & -0.31 & 0.10 & 0.10 & 5.16 & $<0.05$ \\
\hline \multirow{4}{*}{ Mortality rate $(\%)$} & Positive contact & -0.42 & 0.09 & & & \\
\hline & Negative contact & 0.40 & 0.09 & & & \\
\hline & Movements & -0.28 & 0.07 & & & \\
\hline & Size veal unit & -0.22 & 0.05 & 0.30 & 4.66 & $<0.01$ \\
\hline
\end{tabular}

with more positive contacts given to the calves. Farmers' negative contacts and speed of movements during the work with the calves could not be explained by any of the variables included $(P>0.05$; Tab. II).

Gender, the size of the veal unit and education level accounted for $24 \%$ of the variance in attitude to the general importance of contacts for the success of the veal unit (GEN-IMP) $(P<0.01$; Tab. III). Bigger veal units, females, and higher education level, were associated with beliefs that farmers' contacts with calves are important for the success of the veal unit. Gender accounted for $10 \%$ in the variance of the attitude category 'POS-DES', women having a more positive description of their behaviour with calves $(P<0.01$; Tab. III). The other attitude categories, GEN-SENS, SPE-SENS, SPEIMP and NEG-DES, could not be explained by any of the background variables.

\subsection{Relations between productivity results and farmers' behaviour, attitude and background}

Twenty-two percent of the variance in daily weight gain of the calves was accounted for by observed farmers' behaviour with the calves $(P<0.01$; Tab. IV), higher daily weight gain per calf being associated with more positive contacts and more slow and careful movements. Only farmers' contacts with calves significantly accounted for some variance $(10 \%)$ in feed conversion $(P<0.05$; Tab. IV), positive contacts being associated with improved feed conversion. The size of the veal unit and farmers' behaviour with the calves accounted for $30 \%$ of the variance in mortality rates $(P<0.05$; Tab. IV), with lower mortality rates being associated with bigger veal units, more positive contacts and less negative ones, and more slow and careful movements. The productivity results were not associated with any of the attitude categories $(P>0.05)$.

\section{DISCUSSION}

The results of this survey show that the differences between veal units in productivity results and in farmers' behaviour towards calves are linked. The factors most possibly underlying these differences will be discussed.

First of all, the present observations under commercial conditions reveal that, although farmers perform similar acts for milk distribution (opening crates, filling buckets, closing crates), a wide range of different kind of contacts with calves exist around these acts. Analysing these contacts with principal component analysis, showed that most of the contacts which could be regarded beforehand as positive to the 
calves, such as petting, and any form of touching the calves, are opposed to contacts that could be considered as negative, such as slapping with the hand or an object, or kicking. This therefore supports earlier observations on dairy cattle and veal calves in which such acts as stroking the animal's head and letting the animal suck the fingers, were considered as positive, because they further increased the animal's approach of humans [23, 26], whereas acts like slapping animals or kicking them can be considered as negative as they have been reported to increase the animal's avoidance of people [e.g. 10, 14, 27].

The amount of positive contacts farmers gave to their calves was significantly correlated with their beliefs about the sensitivity of the calves to human behaviour and with their description of their own behaviour towards them. These results confirm earlier findings that significant attitude-behaviour relations exist in agriculture $[3,17]$. The description of the farmer's own behaviour was the best predictor of the actual contacts with the calves, as assessed by direct observation. This is consistent with the attitudebehaviour model of Azjen and Fishbein, which underlying principle is that questions most closely related to the attitude subject, i.e. interactions with the calves, will be most predictive of the observed behaviour [7] However, variables other than attitude predicted farmers' contacts with calves. First, the size of the veal unit was a predictor of the amount of positive contacts with the calves, farmers on bigger units showing less positive behaviour. This can be explained in terms of perceived work load with farmers who own bigger units having less time to interact individually with animals [5]. Second, women behaved more positively with calves than men. Until now, only some anecdotal evidence is found for the fact that women behave differently towards animals than men. Grandin [11] stated that progressive feedlots, slaughter plants and auctions are hiring more women to handle animals, because they are thought to be gentler and more careful with them than men. The same reasoning is used to explain that men are more often implicated in farm accidents than women [24]. Results of the present study now give scientific support to these beliefs.

Despite the fact that questions were asked about negative contacts in the questionnaire, negative contacts observed on farmers were not related with their attitudes towards the use of contacts. This lack of correlation could be due to the fact that farmers moderated their responses to questions concerning negative interactions or that they moderated their behaviour, especially their negative contacts, in the presence of the observer. Movements made by the farmers during milk distribution (with no close contacts with the calves) could also not be explained by any of the background or attitude variables. Different reasons can be given for the lack of a link with the attitude categories. First of all, no direct questions towards the importance of speed of movements and gestures were asked in the questionnaire, so the attitude towards speed of movements was not directly measured. Secondly, speed of movement could be due to the work load of the person, but this is unlikely in the present study, as movements and gestures were not related to the size of the veal unit. Finally, it can be supposed that speed of movements and arm gestures are less under a person's control than physical contact with animals. One could argue that, when the work is highly standardised and repetitive, as is the case in veal production, part of the behaviour is due to habit, in the sense that the behaviour has become so routinised through repetition, that a person has ceased to make any conscious decision about performing it [4]. Since attitudes are mostly of influence on behaviours that are under a person's control [7], they might, in this case, predict less accurately the behaviour. Similarly, the performance of negative acts towards the calves could also be partly non-intentional, as a higher amount 
of negative contacts with the calves were associated with rapid and irregular movements made by the farmers during milk distribution.

Farmers on bigger units showed more positive beliefs about the importance of farmers' behaviour on the success of the farm, despite giving less positive contacts to the calves. This supports the hypothesis that high work load can weaken the link between positive attitudes and positive behaviour.

The attitude towards the calves, assessed through the beliefs about the sensitivity of the calves to contact, the beliefs about the importance of farmers' behaviour, and the description of the farmer's own behaviour, were influenced by some of the background variables. One of these variables was gender. Different psychological studies have demonstrated gender differences in attitudes towards animals, all indicating that women had more positive attitudes towards animals than men [8, 20-22]. Furthermore, Hills [21] indicated that within farmers, women had more positive attitudes towards animals, having also higher empathy scores than men. The present study confirms these earlier findings, as female farmers were associated with more positive beliefs about the importance of contacts and the description about their interactions with calves. Moreover, female farmers were observed giving more positive contacts to the calves, and this can result from the more positive attitude they hold towards them.

Farmers behaviour with calves significantly accounted for a part of the variance in productivity and mortality rates of the veal unit. Farmers showing more positive acts towards their calves and more careful movements during their work obtained higher growth rates in their veal units. This confirms earlier findings in pig industry that stockpeople can have an effect on the growth rates, by their behaviour towards the animals $[17,18]$. According to researchers in this area $[1,2,15,16]$, the reason for this effect is that negative human behaviour induces fear reactions in animals towards humans and leads to chronic stress that impairs growth and feed efficiency. The next step in our research will be the inclusion of behavioural observations of the calves and physiological parameters in order to understand how farmer's behaviour acts on the production of veal calves.

When considering the mortality rates of the veal unit, not only the behaviour of the farmer during milk distribution but also the size of the veal unit is of importance, more positive contacts, less negative ones, more slow and careful movements, and bigger veal units being associated with lower mortality rates. It has been demonstrated that poor behaviour by people to animals lead to immuno-suppression and therefore to increased mortality $[12,13]$, through their effect on the health status of the calves. Our future research will also include the estimation of calves' health, in order to fully understand the farmer's effect on animal production.

\section{CONCLUSIONS}

In summary, the present study shows that, in the case of integrated veal production, positive behaviour towards animals is associated with improved productivity of the animals, as seen in other intensive productions. This behaviour largely depends on the farmer's attitudes towards the animals. However, other variables, such as gender or work load, are likely to affect the behaviour of the farmer and final productivity. It seems that the effects of these background variables are not mediated only through their influence on attitudes, but that they can act directly on farmers' behaviour. It is thus recommended that background factors should be included when studying stockperson-animal interactions. 


\section{ACKNOWLEDGEMENTS}

This work has been financed by the European Commission, Directorate General for Agriculture, within the framework of the RTD contract FAIR 2049: "Chain Management of Veal Calf Welfare". The content of this publication is the sole responsibility of its publishers. It in no way represents the views of the Commission or its services. We wish to thank Prof. G. Coleman (Monash University, Australia), and Dr. N. Vialles (University of Montpellier, France) for their advice when constructing the questionnaires and for reviewing the manuscript, Dr. A. Ouedraogo (INRA, Ivry-sur-Seine, France) for his comments and discussion, and Dr. L. Florand (Tendriade Élevage SA, France) for his co-operation during the project.

\section{REFERENCES}

[1] Barnett J.L., Hemsworth P.H., Newman E.A Fear of humans and its relationships with productivity in laying hens at commercial farms, Brit. Poult. Sci. 33 (1992) 699-710.

[2] Barnett J.L., Hemsworth P.H., Hennessy D.P. McMallum T.H., Newman E.A., The effects of modifying the amount of human contact on behavioural, physiological and production responses of laying hens, Appl. Anim. Behav. Sci. 41 (1994) 87-100.

[3] Coleman G.J., Hemsworth P.H., Hay M., Predicting stockperson behaviour towards pigs from attitudinal and job-related variables and empathy, Appl. Anim. Behav. Sci. 58 (1998) 63-75

[4] Eagly A.H., Chaiken S., The Psychology of Attitudes, Harcourt Brace Jovanovitch College Publishers, Fort Worth, TX, 1993.

[5] English P.R., Stockmanship, empathy and pig behaviour, Pig Vet. J. 26 (1991) 56-66.

[6] Fenelon J.P., Qu'est-ce que l'analyse des données?, Lefonen, Paris, 1981

[7] Fishbein M.A., Theory of reasoned action: some applications and implications, in: Howe H.E. Jr., Page M.M. (Eds.), Nebraska Symposium on Motivation, Lincoln University of Nebraska Press, Vol. 27, 1980, pp. 65-116.

[8] Gallup G.G., Beckstead J.W., Attitudes toward animal research, Am. Psychol. 43 (1988) 474-476.

[9] Goldsmith J.R., Paths of association in epidemiological analysis: application to health effects of environmental exposures, Int. J. Epidemiol. 6 (1977) 391-399.

[10] Gonyou H.W., Hemsworth P.H., Barnett J.L. Effects of frequent interactions with humans on growing pigs, Appl. Anim. Behav. Sci. 16 (1986) 269-278.
[11] Grandin T., Introduction: Management and economic factors of handling and transport, in Grandin T. (Ed.), Livestock Handling and Transport, CAB International, Wallingford, Oxon, UK, 1993, pp. 1-9.

[12] Gross W.B., Siegel P.B., Adaptation of chickens to their handlers and experimental results, Avian Dis. 23 (1979) 708-714.

[13] Gross W.B., Siegel P.B., Effects of early environmental stresses on chicken body weight, antibody response to $\mathrm{RBC}$ antigens, feed efficiency and response to handling, Avian Dis. 24 (1979) 569-579.

[14] Hemsworth P.H., Barnett J.L., The effects of aversively handling pigs, either individually or in groups, on their behaviour, growth and corticosteroids, Appl. Anim. Behav. Sci. 30 (1991) 61-72.

[15] Hemsworth P.H., Barnett J.L., Hansen C., The influence of handling by humans on the behaviour, reproduction and corticosteroids of male and female pigs, Appl. Anim. Behav. Sci. 15 (1986) 303-314.

[16] Hemsworth P.H., Barnett J.L., Hansen C., The influence of inconsistent handling by humans on the behaviour, growth and corticosteroids of young pigs, Appl. Anim. Behav. Sci. 17 (1987) 245-252.

[17] Hemsworth P.H., Barnett J.L., Coleman G.J., Hansen C., A study of the relationships between the attitudinal and behavioural profiles of stockpersons and the level of fear of humans and reproductive performance of commercial pigs, Appl. Anim. Behav. Sci. 23 (1989) 301-314.

[18] Hemsworth P.H., Brand A., Willems P., The behavioural response of sows to the presence of human beings and its relation to productivity, Livest. Prod. Sci. 8 (1981) 67-74.

[19] Hemsworth P.H., Coleman G.J., Human-Livestock Interactions: The Stockperson and the Productivity and Welfare of Intensively-farmed Animals, CAB International, New York, NY, USA, 1998

[20] Herzog H.A., Betchart N.S., Pittman R.B., Gender, sex role orientation, and attitudes toward animals, Anthrozoos 4 (1991) 184-191.

[21] Hills A.M., The motivational basis of attitudes toward animals, Soc. Anim. 1 (1993) 111-128.

[22] Kellert S.R., Berry J.K., Attitudes, knowledge, and behaviors toward wildlife as affected by gender, Wildl. Soc. Bull. 15 (1987) 363-371.

[23] Lensink B.J., Boivin X., Pradel P., Le Neindre P., Veissier I., Reducing veal calves' reactivity to people by providing additional human contact, J. Anim. Sci. 78 (2000) 1213-1218.

[24] Mack U., Umgang mit landwirtschaftlichen Nutztieren aus der Sicht der Unfallverhütung, Der Tierzüchter 32 (1980) 50-51. 
[25] Moberg G.P., Suffering from stress: an approach for evaluating the welfare of an animal, Acta Agric. Scand. 27 (Sect. A, Animal Sci. Suppl.) (1996) 46-49.

[26] Munksgaard L., de Passillé A.M., Rushen J., Thodberg K., Jensen M.B., Discrimination of people by dairy cows based on handling, J. Dairy Sci. 80 (1997) 1106-1112.

[27] Paterson A.M., Pearce G.P., Growth, response to humans and corticosteroids in male pigs housed individually and subjected to pleasant, unpleas- ant or minimal handling during rearing, Appl. Anim. Behav. Sci. 34 (1992) 315-328.

[28] Rushen J., de Passillé A.M.B., Munksgaard L., Fear of people by cows and effects on milk yield, behaviour and heart rate at milking, J. Dairy Sci. 82 (1999) 720-727.

[29] SAS, SAS/STAT ${ }^{\odot}$ User's Guide (Release 6.03), SAS Inst. Inc., Cary, NC, 1989.

[30] Seabrook M.F., A study to determine the influence of the herdman's personality on milk yield, J. Agric. Labour Sci. 1 (1972) 45-59. 